\title{
The search for microRNA genes in the regions of two very late genes of Bombyx mori nuclear polyhedrosis virus
}

\author{
T.V. Shirina, A.A. Vislovukh, M.T. Bobrovskaja, E.A. Kozlov
}

Institute of Molecular Biology and Genetics, NAS of Ukraine 150 Academician Zabolotny Str., Kyiv 03680 Ukraine

e.a.kozlov@imbg.org.ua

\begin{abstract}
Aim. B. mori nuclear polyhedrosis virus (NPV) codes two very late genes - polyhedrin (ph) and p10. Search for miRs genes in these regions is of interest because the polyhedra, formed at the very late stage of the virus development, include small RNA of 50-60 nt. The present work was aimed at search for potential precursors of miR transcribed from the late promoter element RTAAG and the TATA promoter elements located in the ph and p10 genes regions. Methods. The search was performed using the bioinformatic programs for miR prediction: MiPred, miRNA SVM, Micropoces- sor SVM, and RNAfold. Results. It has been predicted that the re- gion of ph gene encodes two predicted miRs (bmoNPV-miR-1ph, bmoNPV-miR-2ph) and one predicted potential (C) precursor bmoNPV-pre-miR-1Cph, which is not a Dicer substrate. The region containing p10 gene encodes one predicted miR - bmoNPV-miR- $3 p 10$. Conclusions. A possibility of regulation of the genes orf 1629 and p 74 expression by the predicted miRs, located in the same regions of a complementary chain, is assumed.
\end{abstract}

Keywords: nuclear polyhedrosis virus, Bombyx mori, microRNA, bioinformatic method, prediction.

Introduction. MicroRNA (miRs) are among three most prevailing classes of small non-coding RNAs of 20-30 nucleotides (miRNAs, siRNAs, piRNAs), initiating RNA-interfering. miRs are bioregulators of gene expression in eukaryotic cells. The biogenesis, functioning, biochemical and bioinformatic

(C) Institute of Molecular Biology and Genetics NAS of Ukraine, 2009 approaches to miRs study, their participation in the regulation of various cell processes as well as their relation to some pathology have been previously described in [1]. siRNA, piRNA, and other small non-coding RNA are described in [2]. Besides eukaryotes, miRs are also revealed in viruses, in particular, in large DNA-containing ones [3]. Among RNA-containing viruses miRs were found in human immunodeficiency virus [4, 5]. However, little is 
known about miRs role in the virus-cell interrelations. A few experimental articles and reviews on this problem have been published [6-8].

Baculoviruses are attributed to the class of large DNA-containing viruses. Nuclear polyhedrosis viruses (NPV) are an independent serological group of baculoviruses, virions of which integrate into the inclusion bodies - polyhedra - at the very late stages of the virus development. Polyhedra-forming protein (polyhedrin) is the product of one of two very late genes. The second gene, $p 10$, encodes protein $\mathrm{p} 10$. The expression of both genes is initiated by the late promoter elements $-\mathrm{A} / \mathrm{G} / \mathrm{T} / \mathrm{TAAG}$ [9].

Search for miR precursors (pre-miR) in RNAs, transcribed from two very late promoters of genome of $B$. mori NPV is of interest because the polyhedra of $B$. mori NPV, formed at the very late stage of the virus development, include not only virions, but also small RNA of 50-60 nucleotides [10]. This allowed us suggest their being pre-miR as these molecules are known to be of 50 - 100 nucleotides. Predicted pre-miR, included into polyhedra, is most likely to be processed from the very late transcripts and seized by polyhedrin in the process of polyhedra formation. Both mRNA of polyhedrin and p10 are attributed to these very late transcripts [9]. It is also possible that polyhedra may include either pre-miRs, processed from other late transcripts, or host pre-miR-let7. The rise of miR-let7 synthesis at the stage of larva transformation into pupa was observed by the authors of [11]. We used exactly this stage of the insect development to isolate polyhedra for their investigation (cocoons, containing dead larvae). Further biochemical investigation on RNA from polyhedra would help clearing out which small RNA is included into polyhedra.

The current work presents the results of bioinformatic approach to the search for pre-miRs and miRs not only in the transcripts, synthesized from the TAAG-promoter element for two very late proteins, but also in alternative transcripts (alts), synthesized from the predicted TATA promoter elements, located in the $p h$ and $p 10$ genes regions of the $B$. mori NPV genome.

Materials and Methods. The nucleotide sequence of the genome of $B$. mori NPV was obtained from ICTVdB Management (2006) 00.006.0.01. Nucleopolyhedrovirus
(ICTVdB - The Universal Virus Database, version 4. Columbia University, New York, USA (http://www. ncbi.nlm.nih.gov/ICTVdb/ICTVdB/00.006.0.01.htm).

Among existing programmes for microRNA prediction we selected the ones, the algorithm of which does not have the criterion of conservatism, since viral microRNAs are not conservative in contrast to microRNA of eukaryotes. The secondary structure of alts (hypothetical primary transcripts - h-pri-miR) was investigated using RNAfold programmes (http:// rna.tdi.univie.ac.at/cgibin/RNAfold.cgi) [12]. The programme of predicting and processing pri-miR was used to search for alternative transcripts of sls (stem-loop structure) of 48-150 nt, which are Drosha and Dicer substrates (https://demol.interagon.com/miRNA/). Predicted pre-miR and mature miR were considered as substrates with the score, exceeding the intersection of curves of sensitivity (Se) and specificity (Sp) $->-0,55$ [13]. The hairpins, processed by Drosha, but not processed by Dicer, were considered to be candidate $(C)$.

The nucleotide sequences of hairpin structures, revealed in the alternative transcripts, were also studied using RNAfold programme. The processed hairpins were considered as sls with the value of free energy folding of $-23.0 \mathrm{kcal} / \mathrm{mol}$ [12] or (in terms of kilojoules) -96.6 kilojoules $/ \mathrm{mol}$. Searching for $\mathrm{miR}$ in $B$. mori genome using RNAfold programme, Tong et al. [14] selected the value of free energy "exceeding 105 kilojoules/mol" as a "filter". The value, accepted by us, was 100 kilojoules/mol. The search for real and pseudo pre-miR was performed using miPred programme (http://www.bioinf.seu.edu.cn/ miRNA/index.html) [15].

The search for mature miR in the predicted pre-miR was performed using miRscan programme (http:// genes.mit.edu/miRscan/) [16]. The nucleotide sequence of the investigated pre-miR was introduced in miRscan as the first and second sequences.

Results and Discussion. The late transcription in baculoviruses is initiated by TAAG-promoter element and terminated by polyT-sequence [9]. It is known that three polyhedrin transcripts of 1,$16 ; 3,4$, and 4,9 thousand b.p. [17] and two p10 transcripts of 0.75 and 2.5 thousand b.p. [18] are synthesized in Autographa californica NPV. There are no similar data regarding $B$. mori NPV. Since B. mori NPV is a genotypic variant of A. californica NPV, it is possible to assume the same 
situation for the former. This was our basis for determining the boundaries of genome regions of $B$. mori NPV for the search of miRs. The regions, containing only two predicted polyhedrin transcripts (1.16 and 3.4 thousand b.p.) and both p10 transcripts, were selected for the investigation. This selection was conditioned by the fact that transcripts of 1.16 and 3.4 thousand b.p. cover gene orf 1629, and the transcript of 2.5 thousand b.p. - gene $p 74$, located on the complementary chain. Polyhedrin transcript of 4.9 thousand b.p. was not investigated since it goes beyond the selected region. The location of the defined polyhedrin region in the genome of $B$. mori NPV is $128298-3404$, and that of $\mathrm{p} 10$ region - 108411-110961. If A in AUG codon is taken for the reference point, these regions are -116-3404 (hereinafter ph) and -86-2565 (hereinafter p10), respectively. Transcripts of 1.16 and 3.4 thousand b.p. correspond to transcripts $-51-1129 \mathrm{ph}$ and $-51-3404 \mathrm{ph}$; two p10 transcripts - to transcripts $-71-630 \mathrm{p} 10$ and $-71-$ $2565 \mathrm{p} 10$.

As shown, the secondary structure of $-51-1129 \mathrm{ph}$ transcript contains two stem-loop structures, one of which (slsph) is processed into the mature miR, and the other (sls2ph) does not pass the filters of the programmes, used. The secondary structure of the second transcript $-51-3404$ ph contains 12 hairpins, sls $1 \mathrm{ph}$ among them. Among the remaining stem-loop structures, three do not pass the programme filters and eight are processed only into pre-miRs. Since the figures of secondary structures are too lengthy, they are not presented in the current work, while sls characteristics will be considered further with regard to the discussion of alternative transcripts. $-51-1129 \mathrm{ph}$ is likely to translate into polyhedrin [17].

Therefore, according to our prediction the transcript -51-3404ph may be h-pri-miR. A similar situation is observed for two transcripts of $-86-2565 \mathrm{p} 10$ region. Our data demonstrate that the secondary structure of a smaller transcript ( 0.75 thousand b.p.) contains the only sls1, processed into miR. Besides sls1, a larger transcript (2,5 thousand b.p.) contains six hairpins, which are processed in pre-miR, but do not pass the filters of other programmes. Similar to transcript $-51-3404 \mathrm{ph}$, transcript $-71-2565 \mathrm{p} 10$ may act as h-pri-miR.
Logics of the approach to the search for miR in alternative transcripts are presented below. All the existing programmes of predicting candidate pre-miR are based on the search for some stem-loop structures, corresponding to specific requirements. In reality pre-miR hairpins are processed from the primary transcripts pri-miR. The search for h-pri-miR among alts is complicated, because promoters, from which pri-miR transcription is initiated, are not determined exactly, though pri-miRs are known to be transcribed by RNA-polymerase II from TATA-promoters mainly [19]. The transcription of pri-miRs may take place from other sequences as well [20]. We decided to start the search for miRs from the prediction of h-pri-miRs among various alts. The boundaries of alternative transcripts were determined from predicted promoters TATA to polyT (at least four $\mathrm{T}$ ) sequences.

The region $-116-3404$ ph contains six predicted promoters and 33 polyT-terminating sequences, and the region -86-2565p10 - nine promoters and 19 polyT-sequences. These data were the basis for our investigation of 148 alts-ph and 114 alts-p10. 148 alts-ph contain 19 unique sls-ph. Then unique alternative transcripts were selected according to the following principle: besides the required hairpin, alt, minimal in size, should contain a minimal number of other hairpins. Only 11 unique transcripts out of 148 alts-ph contained all 19 sls-ph, and 16 unique ones out of 114 alts-p10 contained 21 sls-p10. All the results of investigation of sls characteristics are presented in Tables 1 and 2 .

As shown in Table 1, sls3-ph, sls6-ph, sls7-ph, sls10-ph, sls17-ph, sls19-ph are processed from unique alt-ph, while other sls-ph - from two or more alt-ph. Sls1-p10, sls5-p10, sls7-p10, sls9-p10, sls14-p10, sls16-p10, sls18-p10-sls21-p10 are also processed from unique alt-p10 (Table 2). All alts, containing the only processed sls, may be considered as candidates for h-pri-miRs.

The data of Table 1, column 5, demonstrate that 13 sls-ph (sls1-sls6, sls8-sls12, sls16, sls17) are Drosha substrates, while among 21 sls-p10 (Table 2, column 5) - 18 (sls1-sls4, sls6-sls13, sls15-sls17, sls19-sls21) are Drosha substrates. Among 32 selected sls, five sls-ph (sls1, sls3, sls11, sls12, sls16) and five sls-p10 (sls2, sls7, sls8, sls17, sls19) pass the "real" and "pseudo" filters (Tables 1 and 2, column 6). Among 10 
Table 1.

The characteristics of stem-loop structures (sls) in alternative transcripts (alt), synthesized from region 128298-3404 of the B. mori $N P V$ genome encoding $m R N A$ of polyhedrin

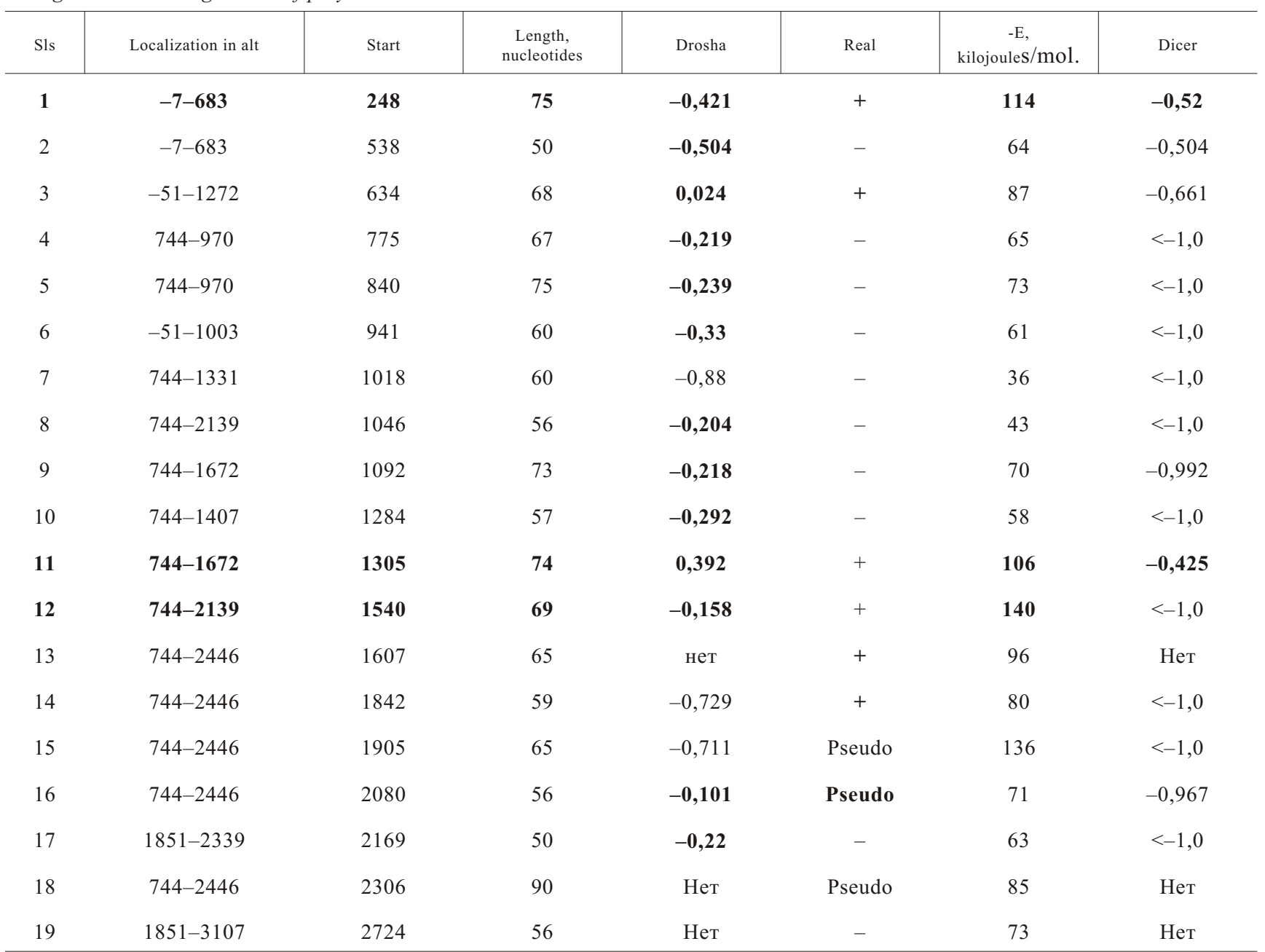

$\mathrm{N}$ o t e. Both here and in Table 2 column 1 presents numbers of sls in the order of less proximity to the reference point. Columns 2 and 3 show localization of alt, containing the corresponding sls, with regard to the reference point and the position of the start nucleotide of sls, respectively. Columns 5 and 8 show the estimation of sls Drosha and Dicer substrates, respectively, in accordance to the programme of predicting and processing pri-miR [13]; "no" means absence of processing centres in the corresponding sls. In column 6 indications «+»«real» hairpin, «-»- hairpin «cannot be real» is in accordance to miPred programme [15]. Column 7 shows the values of free energy of folding of sls in accordance to RNAfold programme [12]. The characteristics of sls, which passed the filters of corresponding programmes, are shown in bold.

selected real and pseudo hairpins, real sls1-ph, sls11-ph, sls12-ph and sls2-p10 pass the RNAfold filter (Tables 1 and 2, column 7). Among four selected "real" and "pseudo" hairpins, three (sls1-ph, sls11-ph, sls2-p10) are Dicer substrates. Therefore we accepted the hairpins, processed from them, as predicted pre-miR and indicated them as bmo-pre-miR-1ph, bmo-pre-miR-2ph and bmo-pre-miR-3p10, respectively, and we considered alts, containing them, as pre- dicted h-pri-miRs (see their location in Tables 1 and 2). Sls12-ph does not pass Dicer filter. The authors of [13] consider hairpins that are not Dicer substrates to be candidate (C) miRs. Therefore, we indicated sls, passing all the filters, but for Dicer, as predicted candidate precursors of miRs - pre-miR-1Cph, and alts, containing them, as corresponding h-pri-miR (see Tables 1 and 2).

Fig. 1 presents secondary structures of three h-pri-miRs. All three h-pri-miRs contain two sls each. 
Table 2.

The characteristics of stem-loop structures (sls) in alternative transcripts (alt), synthesized from region 108281-110842 of the B. mori NPV genome encoding $m R N A$ of 10

\begin{tabular}{|c|c|c|c|c|c|c|c|}
\hline Sls & Локализация в alt & Старт & $\begin{array}{c}\text { Длина, } \\
\text { нуклеотиды }\end{array}$ & Drosha & Real & -Е, кДж/моль & Dicer \\
\hline 1 & $-86-144$ & -83 & 64 & $-0,316$ & - & 40 & $<-1,0$ \\
\hline 2 & $-30-301$ & 66 & 65 & 0,637 & + & 112 & 0,009 \\
\hline 3 & $-30-301$ & 214 & 54 & 0,054 & - & 53 & $<-1,0$ \\
\hline 4 & $-30-491$ & 319 & 76 & $-0,288$ & - & 52 & $<-1,0$ \\
\hline 5 & $323-1556$ & 326 & 89 & $-0,616$ & - & 65 & $<-1,0$ \\
\hline 6 & $-30-491$ & 396 & 70 & 0,326 & - & 70 & $<-1,0$ \\
\hline 7 & $387-611$ & 423 & 95 & $-0,35$ & Pseudo & 77 & $<-1,0$ \\
\hline 8 & $323-1405$ & 686 & 81 & $-0,426$ & + & 88 & $<-1,0$ \\
\hline 9 & $550-980$ & 742 & 57 & 0,093 & - & 51 & $-0,529$ \\
\hline 10 & $-30-980$ & 808 & 48 & $-0,521$ & - & 77 & $<-1,0$ \\
\hline 11 & $323-1405$ & 817 & 62 & $-0,142$ & - & 85 & 0,750 \\
\hline 12 & $-30-980$ & 926 & 51 & $-0,477$ & - & 83 & $<-1,0$ \\
\hline 13 & $550-1307$ & 960 & 47 & $-0,178$ & - & 83 & $-0,943$ \\
\hline 14 & $-71-1112$ & 989 & 65 & Нет & Pseudo & 91 & Нет \\
\hline 15 & $550-1307$ & 1084 & 50 & 0,141 & - & 60 & $-0,067$ \\
\hline 16 & $1203-1307$ & 1203 & 105 & $-0,008$ & - & 131 & $-0,902$ \\
\hline 17 & $323-1405$ & 1222 & 60 & $-0,008$ & Pseudo & 88 & $-0,902$ \\
\hline 18 & $1203-1556$ & 1472 & 81 & $-0,793$ & Pseudo & 102 & $<-1,0$ \\
\hline 19 & $1203-1870$ & 1614 & 58 & $-0,108$ & + & 84 & 0,618 \\
\hline 20 & $411-2565$ & 1952 & 52 & $-0,024$ & - & 99 & $<-1,0$ \\
\hline 21 & $2233-2565$ & 2364 & 83 & $-0,188$ & - & 48 & $<-1,0$ \\
\hline
\end{tabular}

N o t e. See Table 1.

Although sls2-ph is Drosha and Dicer substrate, it is not real, and does not pass the filter of folding free energy (Table 1). As for sls9-ph and sls3-p10, they are Drosha substrates, but they do not pass the filters of other programmes. Therefore, we indicated h-pri-miRs, presented in Fig. 1 as h-pri-miR-1ph, h-pri-miR-2ph and h-pri-miR-3p10. Fig. 2 presents the secondary structure of h-pri-miR-1Cph. Sls11 is processed to mature miR-2ph, and sls 12 - to candidate pre-miR-1Cph. Fig. 3 demonstrates three sls, processed to mature miRs, and one sls, processed to candidate pre-miR-C.
Using the developed programme of predicting virus miRs (Vir-Mirdb), the authors of [21] revealed 11 pre-miR in the plus-strand of the genome of $B$. mori NPV, from which $22 \mathrm{miRs}$ are cut out (one miR from each shoulder of pre-miR). It is hard to agree to these data as a mature miR is usually cut out from one 5 '-shoulder. Besides, all miRs, predicted by the authors of [21], contain 26 nucleotides each, while miRscan has apparently the length of miRs, equal to 21 nucleotides, which is closer to the length of miRs in vivo. The same source of the genome nucleotide sequence was used by 

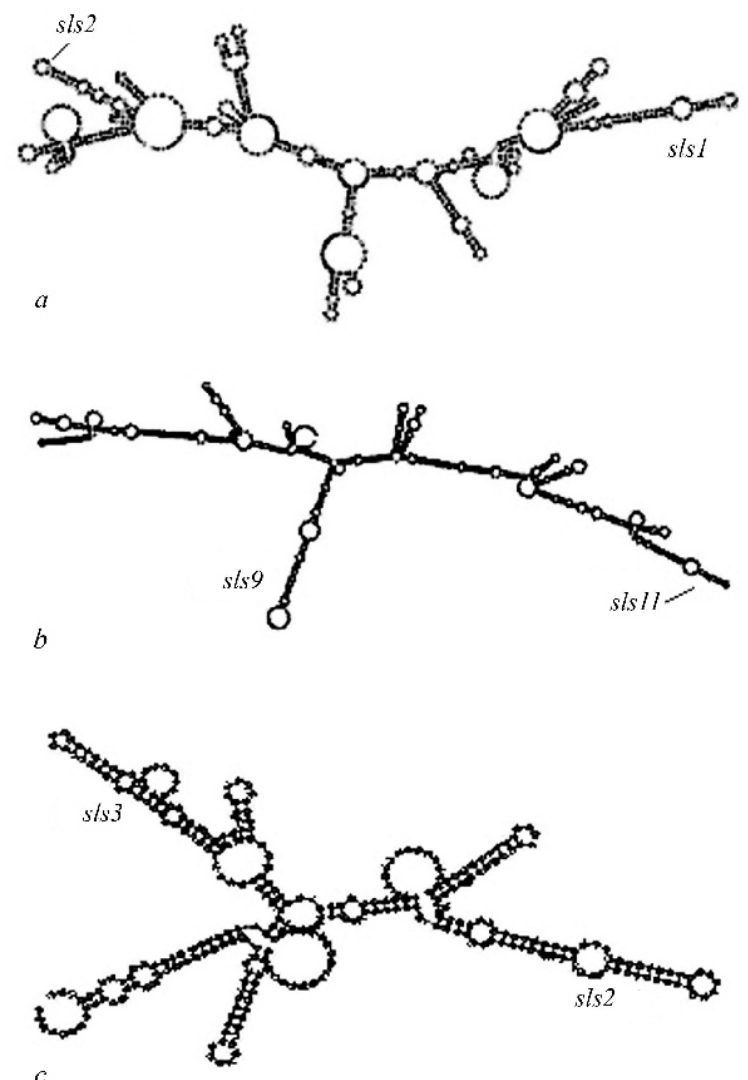

Fig.1 The secondary structures of minimal alternative transcripts, synthesized from putative TATA-promoter to polyT-sequence, accepted as hypothetical pri-miRs, containing a minimal number of stem-loop structures (sls): $a$ - alt-ph - 7-763, accepted as h-pri-miR-1ph (hereinafter the reference point was AUG-codons of mRNA of polyhedrin or $\mathrm{p} 10)$; sls 1 is processed to the mature miR; $b$ - alt-ph 744-1672, accepted as h-pri-miR-2ph (sls 11 is processed to the mature miR); $c$ - alt-p10 30-301, accepted as h-pri-miR-3p10 (only sls2 is processed to the mature miR)

these authors and us; nevertheless, they have not revealed pre-miR-1ph, pre-miR-2ph and pre-miR-3p10, predicted by us. However, they found a hairpin, which suits pre-miR-1Cph, predicted by us. Contrary to their data, this pre-miR-1Cph is not processed by Dicer as Table 1 (sls12) demonstrates.

It is noteworthy that while miR-1ph, miR-2ph and miR-3p10 are the only representatives among h-pri-miRs, predicted by us, they are also found in all investigated alts, containing the regions of their localization. It is possible that predicted mature miRs miR-1ph, miR-2ph and miR-3p10 - will also be present, and therefore, processed in other unknown real alternative transcripts, synthesized in the cell (not only from promoters TATA and TAAG to polyT-sequence). miRs-ph, predicted by us, are completely complementary to mRNA orf 1629, and miR-3p10 - to mRNA $p 74$. Therefore, if these miRs exist, they should function similar to si-RNA. In such case mRNA should split in the regions, complementary to the predicted miRs. Since miRs- 1 ph and miR-3p10 are complementary to 3'-UTR mRNA orf 1629 and p74, respectively, the participation of these miRs in the regulation of expression of genes orf 1629 and $p 74 \mathrm{t}$ may be assumed.

Similar situation is possible for of $A$. californica NPV. As shown in [17], a transcript of 3.2 thousand b.p. is synthesized from the complementary chain in the region of $A$. californica NPV, containing the polyhedrin gene. It contains two open reading frames (orf 1629 and orf 603) and covers the polyhedrin gene. The synthesis of transcript starts prior to mRNA of polyhedrin and it vanishes with the appearance of polyhedrin, though its fragments are still observed.

In 1990 the authors explained this phenomenon by three reasons: 1) destruction of promoter complexes from the 3'-end of polyhedrin gene by RNA-polymerase, transcribing polyhedrin; 2) formation of double-stranded RNA from polyhedrin mRNA; 3 ) negative regulation of promoter orf 1629 by polyhedrin. At that time they could not assume the participation of microRNA in this process, as microRNAs were discovered only in the beginning of this century. We assume the participation of miR, encoded in polyhedrin gene, in the regulation of synthesis of the transcript, containing orf 1629 and orf 603. In this case transcript of 3.2 thousand b.p. will be split. We plan further investigation on the detection of miRs in the region of the genome of A. californica NPV, containing polyhedrin genes orf 1629 and orf 603.

\section{Т. В. Ширина, А. А. Висловух, М. Т. Бобровская, Э. А. Козлов}

Поиск генов микроРНК в участках генома, содержащих два очень поздних гена вируса ядерного полиэдроза Bombyx mori

Резюме

Цель. Вирусы ядерного полиэдроза (ВЯП) В. тогі кодируют два очень поздних гена - ph и p10. Интерес к поиску генов miR в этих участках генома обусловлен тем, что полиэдры, образующиеся на очень поздней стадии инфекиии, включают в себя не только вирионы, но и малую РНК длиной 50-60 нуклеотидов. Цель настоящего сообщения состояла в поиске тіRs в альтер- 


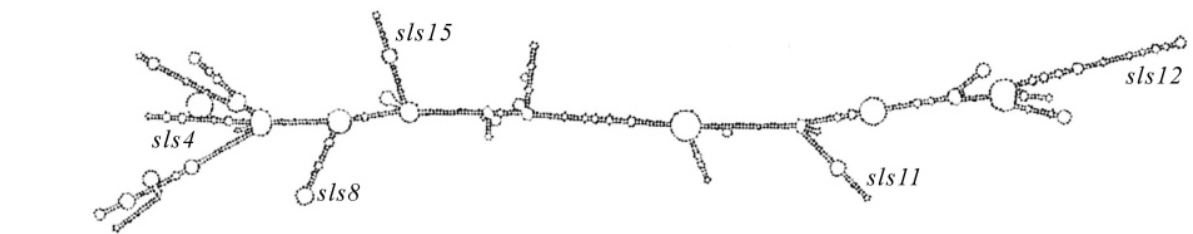

Fig.2 The secondary structure of alt-ph 744-2139, accepted as h-pri-miR-1Cph (only sls 12 is processed to pre-miR-1Cph)

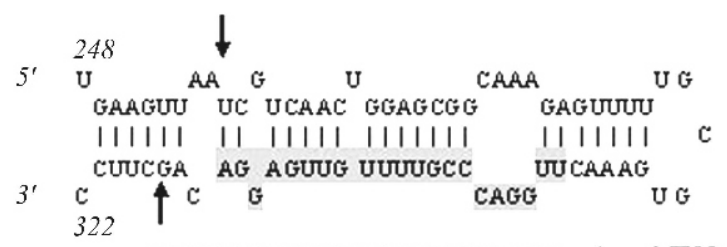

UUGGACCCGUUUUGUUGAGGA bmoNPV-miR-1ph

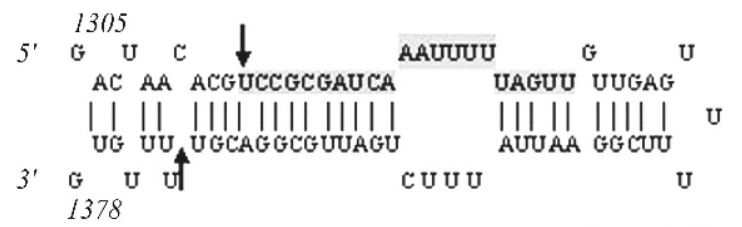

UCCGCGAUCAAAUUUUUAGUU bmoNPV-miR-2ph

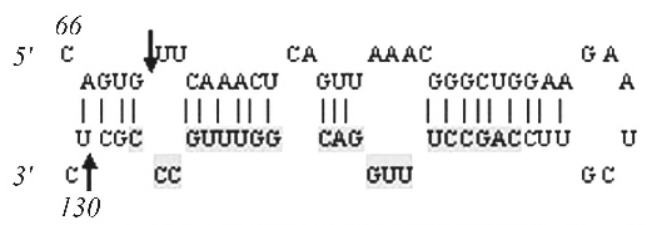

CAGCCUUUGGaCGGUUUGCCC bmoNPV-miR-3p 10

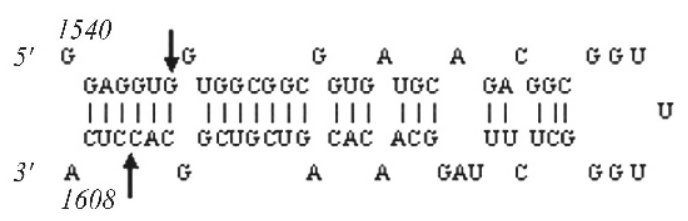

bmoNPV -pre-miR-1Cph

d

Fig. 3 The secondary structures of sls1-ph $(a)$, sls11-ph $(b)$, sls2-p10 (c), sls12-ph $(d)$ and predicted miRs. The centers of processing by Drosha to hairpins pre-miR-1ph, pre-miR-2ph, pre-miR-3p10, pre-miR-1Cph are indicated with arrows. The mature miRs, present in pre-miRs, are shaded.

нативных транскриптах, синтезируемых не только с ТАAG-промоторного элемента, но и с ТАТА-промоторных элементов, расположенных в участках генома ВЯП В. тогі, включаюших гены ph и p10. Методы. Поиск тіRs осуществляли с помощью биоинформатических программ предсказания тіR: MiPred, miRNA SVM, Micropocessor SVM и RNAfold. Результатыл. Предсказано, что участок, содержаший ген рh, может кодировать две miRs (bmoNPV-miR-1ph, bmoNPV-miR-2ph) $u$ один потенциальный (C) предшественник miR bmoNPV-pre-miR-1Cph, не являющийся субстратом для фермента Dicer. Участок, содержащий ген р10, может кодировать одну предска- занную miR - bmoNPV-miR-3p10. Выводы. Обсуждается возможность регуляции экспрессии предсказанными miRs генов orf 1629 и р74, расположенных в тех же участках комплементарной иени.

Ключевые слова: вирус ядерного полиэдроза, Вотbух mori, микроРНК, биоинформатический подход, предсказание.

\section{T. В. Ширина, А. А. Висловух, М. Т. Бобровська, Е. А. Козлов}

Пошук генів мікроРНК у ділянках геному, які містять два дуже пізніх гени вірусу ядерного поліедрозу Bombyx mori

Резюме

Мета. Віруси ядерного поліедрозу (ВЯП) В. тогі кодують два дуже пізніх гени - ph і p10. Інтерес до пошуку тіR у ицих ділянках геному обумовлений тим, щь поліедри, які утворюються на дуже пізній стадії інфекиії, містять у собі не тільки віріони, але й малу РНК довжиною 50-60 нуклеотидів. Мета даного повідомлення полягала в пошуку тіRs в альтернативних транскриптах, синтезованих не лише з TAAG-промоторного елемен- та, а й з ТАТА-промоторних елементів, розташованих у ділянках геному ВЯП В. тогі, що включають гени ph і p10. Методи. Пошук miRs здійснювали за допомогою біоінформатичних програм передбачення miR: MiPred, miRNA SVM, Micro- pocessor SVM i mFOLD. Результати. Передбачено, шоо ділянка, в якій локалізується ген ph, може кодувати дві miRs (bmoNPV-miR-1ph, bmoNPV-miR-2ph) ma nотенційний попередник miR - bmoNPV-pre-miR-1Cph, шчо не є субстратом для ферменту Dicer. Ділянка, y якій розмішений ген р10, може кодувати одну miR - bmoNPV-miR-3p10. Висновки. Обговорюється можливість регуляиї̈ експресї̈ передбаченими тіRs генів оrf1629 и р74, розташованих на тих же ділянках комплементарного ланиюга.

Ключові слова: вірус ядерного поліедрозу, Bотbух mori, мікроРНК, біоінформатичний підхід, передбачення.

\section{REFERENCES}

1. Shirina T. V., Bobrovskaya M. T., Kozlov E. A. MicroRNA: from fundamental research to their application // Biopolymers and Cell.-2007.-23, N 6.-P. 467-482.

2. Makarova J. A., Kramerov D. A. Noncoding RNAs // Biokhimia.-2007.-72, N 11.-C. 1427-1448.

3. Nelsen J. A. Small RNA and large DNA viruses // N. Engl. J. Med.-2007.-357, N 26,-P. 2630-2672.

4. Omoto S., Fujii Y. R. Cloning and detection of HIV-1-encoded microRNA// Meth. Mol. Biol..-2006.-342.-P. 255-265.

5. Klase Z., Kale P., Winograd R., Gupta M. V., Heydarian M., Bezzo R., Mc Caffrey T., Kashanchi F. HIV-1 TAR element is processed by Dicer to yield a viral microRNA involved in 
chromatin remodeling of the viral LTR // BMC Mol. Biol.2007.-8.-P. 63-81.

6. Scaria V., Hariharan M., Pillai B., Maiti S., Brahmachari S. $K$. Host-virus genome iteraction: macro roles for microRNAs // Cell Microbiol.-2007.-9, N 12.-P. 2784-2794.

7. Yeung M., L., Benkirane M., Jeang K.-T. Small non-coding RNAs, mammalian cells, and viruses: regulatory interaction? // Retrovirology.-2007.-4.-P. 74-79.

8. Hakim S. T., Alsayari M., Mc Lean D. C., Saleem S., Addanki K. C., Aggarwal M., Mahalingam K., Bagasra O. A large number of the human microRNAs target lentiviruses, retroviruses, and endogenous retroviruses // Biochem. and Biophys. Res. Communs.-2008.-369, N 2.-P.357-362.

9. Okano K., Vanarsdall A. L., Mikhailov V. S., Rohrman G. F. Conserved molecular systems of the baculoviridae // Virology.-2006.-344, N 1.-P. 77-87.

10. Kozlov E. A., Vudmaska M. I., Bobrovskaja M. T., Shirina T. $V$. Investigation of structure-function interaction of polyhedron of Bombyx mori Nuclear Polyhedrosis Virus (NPV) with polyhedra protease and RNA. 3. Polyhedras contain small RNA // Biopolymers and Cell.-2007 - 23, N 4.-P. 301-306.

11. Liu S., Xia Q., Zhao P., Cheng T., Hong K., Xiang Z. Characterization and expression patterns of let-7 microRNA in the silkworm (Bombyx mori) // BMC Develop. Biol.-2007.-25, N 7.-P. 88-104.

12. Zuker $M$. Mfold web server for nucleic acid folding and hybridization prediction // Nucl. Acids Res.-2003.-31, N 13.P. 3406-3415.

13. Helvik S. A., Snove O., Saetrom P. Reliable prediction of Drosha processing sites improves microRNA genes prediction // Bioinformatics.-2007.-23, N 2.-P. 142-149.

14. Tong C., Jin Y., Zhang Y. Computational prediction of microRNA genes in silkworm genome // J. Zhejiang Univ. SCIENCE B.-2006.-7, N 10.-P. 806-816.
15. Xue C., Li F., He T., Liu G. P., Li Y., Zhang X. Classification real and pseudo microRNA-precursor using local structuresequence features and support vector mashine // Bioinformatics.-2005.-6, N3.-P. 310-316.

16. Lim L. C., Lau N. C., Weinstein E. G., Abdelhakim A., Yekta S., Rhoades M. W., Burge C. B., Bartel D. P. The microRNAs of Caenorhabditis elegans // Genes Develop.-2003.-17, N 8.- P. 991-1008.

17. Ooi B. G., Miller L. K. Transcription of the baculovirus polyhedrin gene reduces the levels of an antisense transcript initiated downstream // J. Virol.-1990.-64, N 6.-P. 31263129.

18. Liu A., Qin J., Rankin C., Hardin S. E., Weaver R. F. Nucleotide sequence of a portion of the Autographa californica nuclear phyhedrosis viruses genome containing the EcoR 1 site-rich region $\left(\mathrm{h} 2_{5}\right)$ and open reading frame just 5' $p 10$ gene // J. Gen. Virol.-1986.-67, N 11.-P. 2565-2570.

19. Lee J., Kim M., Han J., Yeom K.-H., LeeS., BackS. H., Kim V. $N$. MicroRNA genes are transcribed by RNA phymerase II // EMBO J.-2004.-23.-P. 4051-4060.

20. Fujita $S$., Iba $H$. Putative promoter regions of microRNAs genes involved in evolutionarily conserved regulatory systems among vertebrates // Bioinformatics.-2008.-24, N 3.-P. 303-308.

21. Li S.-C., Shiau C.-K., Lin W.-C. Vir-MiR db: prediction of viral microRNA candidate hairpins // Nucl. Acids Res.-2008.36, N 1.-P. 184-189.
UDC 577.214:578.841

Received 09.06.08 